\title{
Differential Localization of $\delta$ Glutamate Receptors in the Rat Cerebellum: Coexpression with AMPA Receptors in Parallel Fiber-Spine Synapses and Absence from Climbing Fiber-Spine Synapses
}

\author{
Alf Sommer Landsend, ${ }^{1}$ Mahmood Amiry-Moghaddam, ${ }^{1}$ Atsushi Matsubara, ${ }^{2}$ Linda Bergersen, ${ }^{1}$ \\ Shin-ichi Usami, ${ }^{2}$ Robert J. Wenthold, ${ }^{3}$ and Ole P. Ottersen 1 \\ ${ }^{1}$ Department of Anatomy, Institute of Basic Medical Sciences, University of Oslo, N-0317 Oslo, Norway, ${ }^{2}$ Department of \\ Otorhinolaryngology, Hirosaki University School of Medicine, Hirosaki 036, Japan, and ${ }^{3}$ Laboratory of Neurochemistry, \\ National Institute on Deafness and Other Communication Disorders, National Institutes of Health, Bethesda, \\ Maryland 20892
}

\begin{abstract}
The $\delta 2$ glutamate receptors are prominently expressed in Purkinje cells and are thought to play a key role in the induction of cerebellar long-term depression. The synaptic and subsynaptic localization of $\delta$ receptors in rat cerebellar cortex was investigated with sensitive and high-resolution immunogold procedures. After postembedding incubation with an antibody raised to a C-terminal peptide of $\delta 2$, high gold particle densities occurred in all parallel fiber synapses with Purkinje cell dendritic spines, whereas other synapses were consistently devoid of labeling. Among the types of immunonegative synapse were climbing fiber synapses with spines and parallel fiber synapses with dendritic stems of interneurons. At the parallel fiber-spine synapse, gold particles signaling $\delta$ receptors were restricted to the postsynaptic specialization. By the use of double labeling
\end{abstract}

with two different gold particle sizes, it was shown that $\delta$ and AMPA GluR2/3 receptors were colocalized along the entire extent of the postsynaptic specialization without forming separate domains. The distribution of gold particles representing $\delta$ receptors was consistent with a cytoplasmic localization of the $\mathrm{C}$ terminus and an absence of a significant presynaptic pool of receptor molecules. The present data suggest that the $\delta 2$ receptors are targeted selectively to a subset of Purkinje cell spines and that they are coexpressed with ionotropic receptors in the postsynaptic specialization. This arrangement could allow for a direct interaction between the two classes of receptor.

Key words: immunogold; glutamate receptor; freeze substitution; colocalization; synapse; cerebellum
The $\delta$ glutamate receptors ( $\delta 1$ and $\delta 2)$ constitute a separate family of proteins that, on the basis of their amino acid sequence, has been positioned between the NMDA and AMPA receptor families (Yamazaki et al., 1992; Araki et al., 1993; Lomeli et al., 1993). Yet the functional properties of the $\delta$ receptors seem to differ fundamentally from those of the ionotropic receptors: they do not form functional ion channels when expressed in transfected cells (Araki et al., 1993; Lomeli et al., 1993) and do not bind glutamate or glutamate agonists such as AMPA and kainate (Lomeli et al., 1993; Mayat et al., 1995).

Important insight into the possible roles of the $\delta 2$ subunit was provided recently by analyses of mutant mice that lacked this receptor (Hirano et al., 1995; Kashiwabuchi et al., 1995). This $\delta$ subunit normally is predominantly expressed in the cerebellum (Araki et al., 1993; Lomeli et al., 1993; Mayat et al., 1995; Takayama et al., 1995). In agreement, the mutant mice exhibited defects that could be attributed to cerebellar dysfunction, such as an impairment of motor coordination (Kashiwabuchi et al., 1995).

Received Sept. 3, 1996; revised Oct. 23, 1996; accepted Nov. 5, 1996.

This work was supported by the Norwegian Research Council, J. E. Isberg's Fund, the European Union Biomed Program (BMH4-CT960851), and the Sasakawa Foundation. We thank B. Riber, K. M. Gujord, G. Lothe, and T. Nordby for technical assistance.

Correspondence should be addressed to Dr. Ole P. Ottersen, Department of Anatomy, Institute of Basic Medical Sciences, University of Oslo, P.O. Box 1105 Blindern, N-0317 Oslo, Norway.

Copyright (C) 1997 Society for Neuroscience $0270-6474 / 97 / 170834-09 \$ 05.00 / 0$
This was accompanied by a strong reduction in cerebellar longterm depression (LTD), confirming previous studies based on the use of antisense technology (Hirano et al., 1994). LTD has been proposed as a cellular correlate of motor learning (Ito, 1989) and is thought to be mediated by alterations in the number or sensitivity of AMPA receptors (Linden, 1994).

The mechanisms by which the $\delta 2$ receptor contributes to LTD have not been resolved. Among other things one needs to know how this subunit is organized at cerebellar synapses. Light and electron microscopic studies based on standard pre-embedding immunocytochemistry (Mayat et al., 1995; Takayama et al., 1995) suggested that the $\delta 2$ receptor is localized primarily in Purkinje cells and that it is concentrated at the parallel fiber-Purkinje cell synapses - the locus of LTD expression (Linden, 1994). However, reflecting the limitations of immunoperoxidase procedures (see discussion in Baude et al., 1995), no data were obtained on the arrangement of the $\delta 2$ receptors in synaptic and nonsynaptic membranes, their relative levels of expression in different types of synapse, and their spatial relation to AMPA receptors. The aim of the present study was to provide such information. To this end we have used a postembedding immunogold procedure that has been refined for optimum sensitivity and ultrastructural preservation (Matsubara et al., 1996).

\section{MATERIALS AND METHODS}

Tissue preparation. Male Wistar rats $(250-300 \mathrm{gm} ; n=3)$ were anesthetized with sodium pentobarbital $(50 \mathrm{mg} / \mathrm{kg})$ and subjected to transcardiac 
perfusion with $2 \%$ dextran (MW 70,000) in 0.1 M sodium phosphate buffer (PB; $\left.\mathrm{pH} 7.4,4^{\circ} \mathrm{C}, 15 \mathrm{sec}\right)$, followed by a mixture of glutaraldehyde $(0.1 \%)$ and formaldehyde (4\%; freshly depolymerized from paraformaldehyde) in the same buffer (room temperature, $50 \mathrm{ml} / \mathrm{min}$ for $20 \mathrm{~min}$ ). The brain was left in situ overnight $\left(4^{\circ} \mathrm{C}\right)$. Specimens from the cerebellum (lobule VI) and hippocampus (CA1) were isolated, cryoprotected in graded concentrations of phosphate-buffered glycerol, and rapidly frozen in liquid propane $\left(-170^{\circ} \mathrm{C}\right)$ in a cryofixation unit (Reichert KF80, Vienna, Austria). The specimens were transferred to $0.5 \%$ uranyl acetate dissolved in anhydrous methanol $\left(-90^{\circ} \mathrm{C}\right)$ in a cryosubstitution unit (AFS; Reichert). The temperature was raised stepwise to $-45^{\circ} \mathrm{C}$. The samples were infiltrated with Lowicryl HM20 resin (Lowi, Waldkraiburg, Germany), and polymerization was induced by UV light for $48 \mathrm{hr}$. A detailed description of the procedure has been published (Hjelle et al., 1994; Chaudhry et al., 1995) (also see van Lookeren Campagne et al., 1991).

Immunoincubation. Ultrathin sections were mounted on nickel grids or gold-coated grids and processed for immunogold cytochemistry as described by Matsubara et al. (1996). Briefly, the sections were treated with a saturated solution of $\mathrm{NaOH}$ in absolute ethanol $(2-3 \mathrm{sec})$, rinsed, and incubated sequentially in (1) $0.1 \%$ sodium borohydride and $50 \mathrm{~mm}$ glycine in Tris buffer containing $0.05 \mathrm{M} \mathrm{NaCl}$ and $0.1 \%$ Triton $\mathrm{X}-100$ (TBNT); (2) $2 \%$ human serum albumin (HSA) in TBNT; (3) antibodies to $\delta$ or AMPA receptors $(1 \mu \mathrm{g} / \mathrm{ml}$ and $2 \mu \mathrm{g} / \mathrm{ml}$, respectively) in TBNT and $2 \%$ HSA; (4) 2\% HSA in TBNT; and (5) goat anti-rabbit immunoglobulins coupled to $5,10,15$, or $30 \mathrm{~nm}$ gold particles (Amersham, Arlington Heights, IL) and diluted 1:20 in TBNT with $2 \%$ HSA or with $2 \%$ HSA and $5 \mathrm{mg} / \mathrm{ml}$ polyethyleneglycol. Finally, the sections were counterstained and examined in a Philips CM10 transmission electron microscope.

Double labeling was performed as described by Ottersen et al. (1992), using formaldehyde vapor (Wang and Larsson, 1985) to prevent interference between the sequential incubations. GluR2/3 and $\delta$ receptors were distinguished by means of different gold particle sizes (10 or $15 \mathrm{~nm}$ for GluR2/3 and 30 or $5 \mathrm{~nm}$ for $\delta$ ).

Antisera. The $\delta$ receptor antibody was raised against a synthetic peptide (QPTPTLGLNLGNDPDRGTSI) corresponding to the C terminus of the rat glutamate $\delta 2$ receptor subunit (Mayat et al., 1995). This antibody also recognizes the $\delta 1$ receptor subunit but does not label other glutamate receptors, including AMPA and NMDA receptors (Mayat et al., 1995). The AMPA receptor antibody (Ab 25; Wenthold et al., 1992) reacts with GluR2 as well as GluR3. Both antibodies were affinity-purified.

Control experiments. The $\delta$ receptor antibody $(1 \mu \mathrm{g} / \mathrm{ml})$ was substituted with $1 \mu \mathrm{g} / \mathrm{ml}$ nonimmune IgG or preadsorbed with $50 \mu \mathrm{g} / \mathrm{ml}$ of one of the following peptides: (1) peptide corresponding to the C-terminal 20 amino acids of the $\delta 2$ receptor (i.e., the peptide used for immunization), (2) peptide corresponding to amino acids 850-862 of AMPA GluR2 (used to generate the AMPA GluR2/3 antibody), or (3) peptide corresponding to amino acids $877-889$ or $868-881$ of AMPA GluR1 or GluR4, respectively (Wenthold et al., 1992). Controls for double labeling included omission of the first or the second primary antibody and reversal of the antibody sequence.

Quantitative analysis. Different types of synapse were identified on morphological criteria (Palay and Chan-Palay, 1974) in electron micrographs sampled throughout the thickness of the cerebellar cortex. For each transversely cut synaptic profile with well defined postsynaptic density, the length of the postsynaptic specialization was measured, and the number of associated gold particles was counted. The immunolabeling density was expressed as the number of gold particles per micrometer of postsynaptic specialization.

The distribution of labeling along the axis perpendicular to the postsynaptic density was assessed at high magnification by recording the distance between the midpoint of the postsynaptic membrane and the centers of the gold particles.

The lengths of the postsynaptic membranes relative to the total plasma membrane lengths were estimated in micrographs according to the procedure described by Gundersen et al. (1988), using a transparent overlay with lines arranged in a regular tessellation. Intersections with profile boundaries were recorded only where the membranes were distinct, thus excluding any membrane that had been obliquely cut by the plane of section. The number of gold particles associated with synaptic and nonsynaptic membranes was counted.

The cross-sectional area of spines relative to the total area of the analyzed tissue was calculated by point counting, using an overlay similar to that described above (Gundersen et al., 1988).

\begin{tabular}{llll}
\hline $\begin{array}{l}\text { Table 1. Immunoreactivity for the } \boldsymbol{\delta 2} \text { receptor at different types of } \\
\text { synapse }\end{array}$ & $\begin{array}{l}\text { Number } \\
\text { of PSDs }\end{array}$ & $\begin{array}{l}\text { Total length } \\
(\mu \mathrm{m})\end{array}$ & $\begin{array}{l}\text { Number of gold } \\
\text { particles per } \mu \mathrm{m}\end{array}$ \\
PSDs $( \pm$ SD)
\end{tabular}

Quantitative assessment of $\delta$ receptor immunogold labeling. The data were obtained from a single section (represented in Figs. 1, 2; $15 \mathrm{~nm}$ gold particles) to ensure identical incubation conditions. Note selective labeling of postsynaptic densities (PSDs) of synapses between parallel fibers and Purkinje cell spines. The number and total length of the postsynaptic densities are indicated.

\section{RESULTS \\ Differential expression of $\delta 1 / \delta 2$ receptors at cerebellar synapses}

As noted in Materials and Methods, the $\delta$ receptor antibody recognizes the $\delta 1$ as well as the $\delta 2$ subunit. Among the different synapses in the cerebellar cortex only those between parallel fibers and Purkinje cell spines exhibited significant immunolabeling for $\delta 1 / \delta 2$ receptors (Table 1 ; Figs. $1-3$ ). The linear density of gold particles at this type of synapse was 20 per micrometer, while no particles were recorded at other synapses in the sample (Table 1). Immunonegative synapses included those between climbing fibers and Purkinje cell spines (Fig. $2 A$ ), between mossy fiber terminals and granule cell dendritic digits (Fig. $2 B$ ), and between parallel fibers and dendritic stems (Fig. $3 A, B$ ). Densities postsynaptic to terminals of stellate cells (Fig. $3 B$ ) or basket cells (not illustrated) also were devoid of labeling. Similarly, no or, in some cases, a single gold particle was found to be associated with asymmetric spine synapses in the stratum oriens and radiatum of the hippocampus (Fig. 3B, inset). The hippocampal sections had been incubated together with those from the cerebellum to ensure identical incubation conditions. The same pattern of labeling was obtained in each of the three animals subjected to investigation.

Replacement of the primary antibody with nonimmune IgG or preadsorption with the peptide used for immunization (Fig. $2 B$, right inset) abolished the labeling, whereas preadsorption with AMPA receptor peptides had no effect (Fig. 2B, left inset).

\section{Synaptic versus nonsynaptic expression of $\delta 1 / \delta 2$ receptors}

In preparations based on the use of $15 \mathrm{~nm}$ gold particles (which gave negligible background labeling; see legend to Table 2) 90\% of the total number of particles in the molecular layer was associated with the postsynaptic specializations of parallel fiber synapses with spines (Table 2; Figs. 1, 2, 3A). The postsynaptic specializations constitute $3 \%$ of the total boundary length in the sampled area (Table 2), implying an $\sim 800$-fold enrichment of the labeling at these sites. Approximately one-third (32\%) of the particles that were situated outside of postsynaptic densities could be attributed to nonsynaptic membranes, while the remaining particles occurred over cytoplasmic compartments (Table 2).

The few particles that were associated with nonsynaptic membranes did not seem to show any preference for specific membrane compartments. Notably, there was no enrichment of immunoreactivity in the glial membranes that surround the parallel fiber-spine synapses (Figs. 1,2) or in the spine plasma membranes lateral to the postsynaptic densities. 


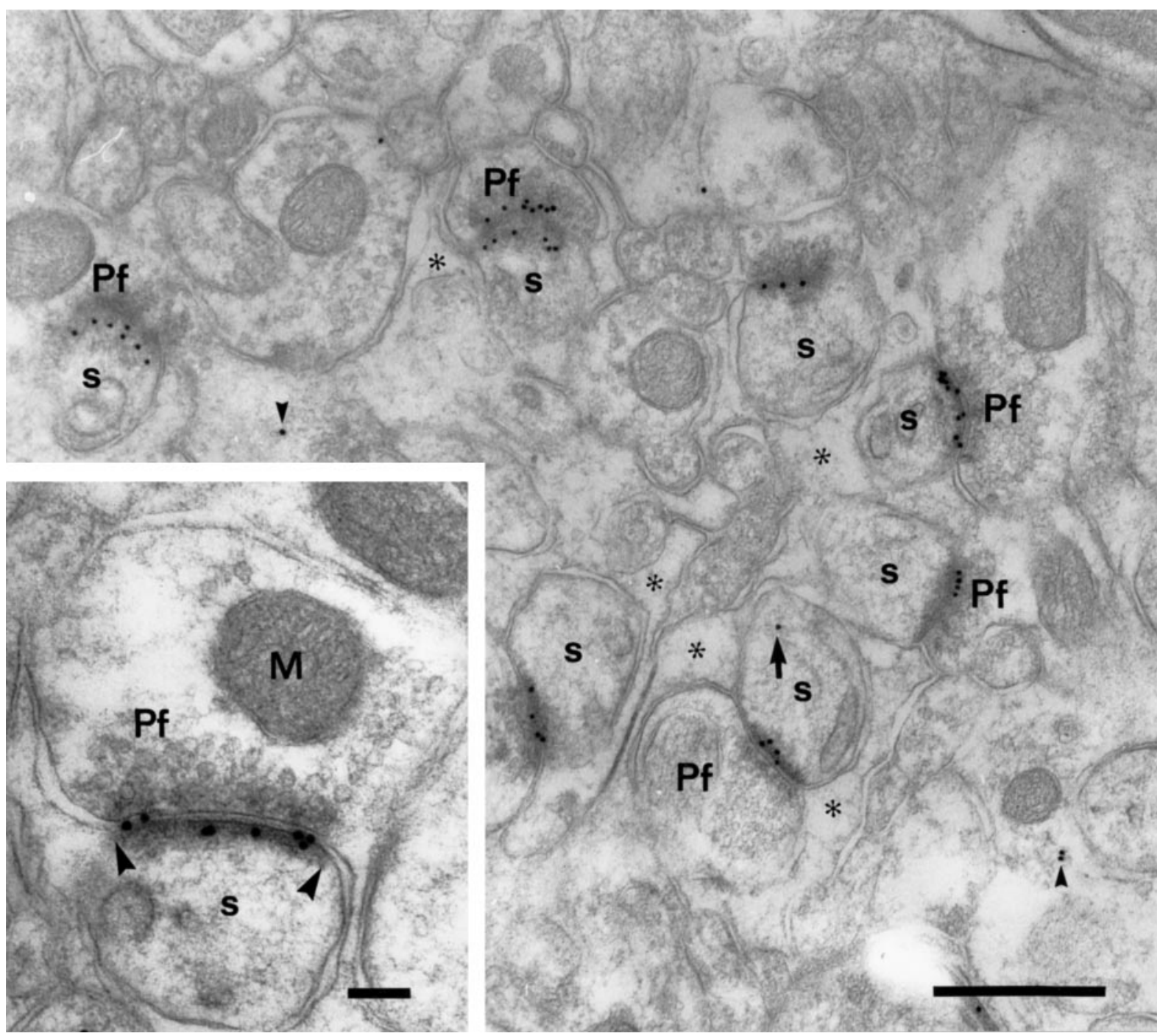

Figure 1. Distribution of $\delta$ receptor immunoreactivity at synapses between parallel fibers $(P f)$ and Purkinje cell spines $(s)$. Seven synapses of this category are shown in the micrograph, and each displays at least three gold particles. The synapse at top center is obliquely cut, the two rows of particles representing receptors exposed at opposite surfaces of the section. Asterisks indicate glial lamellae. Only seven particles are not associated with any postsynaptic density; of these, one is found within a spine (arrow) and two within other intracellular compartments (arrowheads). Inset, Higher magnification of a parallel fiber synapse. Gold particles occur along the entire postsynaptic density (delimited by arrowheads). M, Mitochondrion. Gold particles, $15 \mathrm{~nm}$. Scale bars: 0.5 $\mu \mathrm{m}$; inset, $0.1 \mu \mathrm{m}$.

The interior of the spines contained $\sim 25 \%$ of the particles that were located in cytoplasmic compartments (Figs. 1A, arrow; $3 A$, arrowhead), yet the spines constituted only $6 \%$ of the volume (Table 2). Although this could point to a modest enrichment of immunoreactivity within the spines, it must be noted that the particle numbers were small. All particles that were recorded as belonging to the spine cytoplasm were located $>28 \mathrm{~nm}$ away from the postsynaptic specialization and thus could not be attributed to the receptors at this site (Matsubara et al., 1996).

\section{Organization of $\delta 1 / \delta 2$ receptors in the postsynaptic densities}

Gold particles signaling $\delta$ receptors were found along the entire extent of the postsynaptic specialization (Fig. 1, inset). The quantitative analysis revealed that the density of labeling was quite uniform from the center to the periphery of the synapse, except for a slight reduction near the margin of the postsynaptic thickening (Fig. 4A). This pattern of distribution was reproduced in individual subpopulations of the total sample of synapses (data not shown). As to the distribution of gold particles along the axis perpendicular to the synaptic specialization, it was found that $83 \%$ of the particles were localized postsynaptic to the midpoint of the postsynaptic membrane (Fig. 4B).

\section{Comparative distribution of $\delta 1 / \delta 2$ and AMPA receptors}

Double-labeled preparations that used two different gold particle sizes revealed a colocalization of $\delta 1 / \delta 2$ and AMPA GluR2/3 receptors at the parallel fiber synapses with spines (Fig. $5 A-$ $E, G, H)$. In contrast, postsynaptic densities facing climbing fibers (Fig. $5 F$ ) were single-labeled for AMPA receptors. The same was true of mossy fiber synapses and parallel fiber synapses with dendritic stems (data not shown).

The gold particles signaling AMPA receptors occurred throughout the postsynaptic specialization of the parallel fiberspine synapses and were intermingled with those signaling $\delta 1 / \delta 2$ receptors (Fig. $5 A-E$ ). Reversal of the antibody sequence did not 

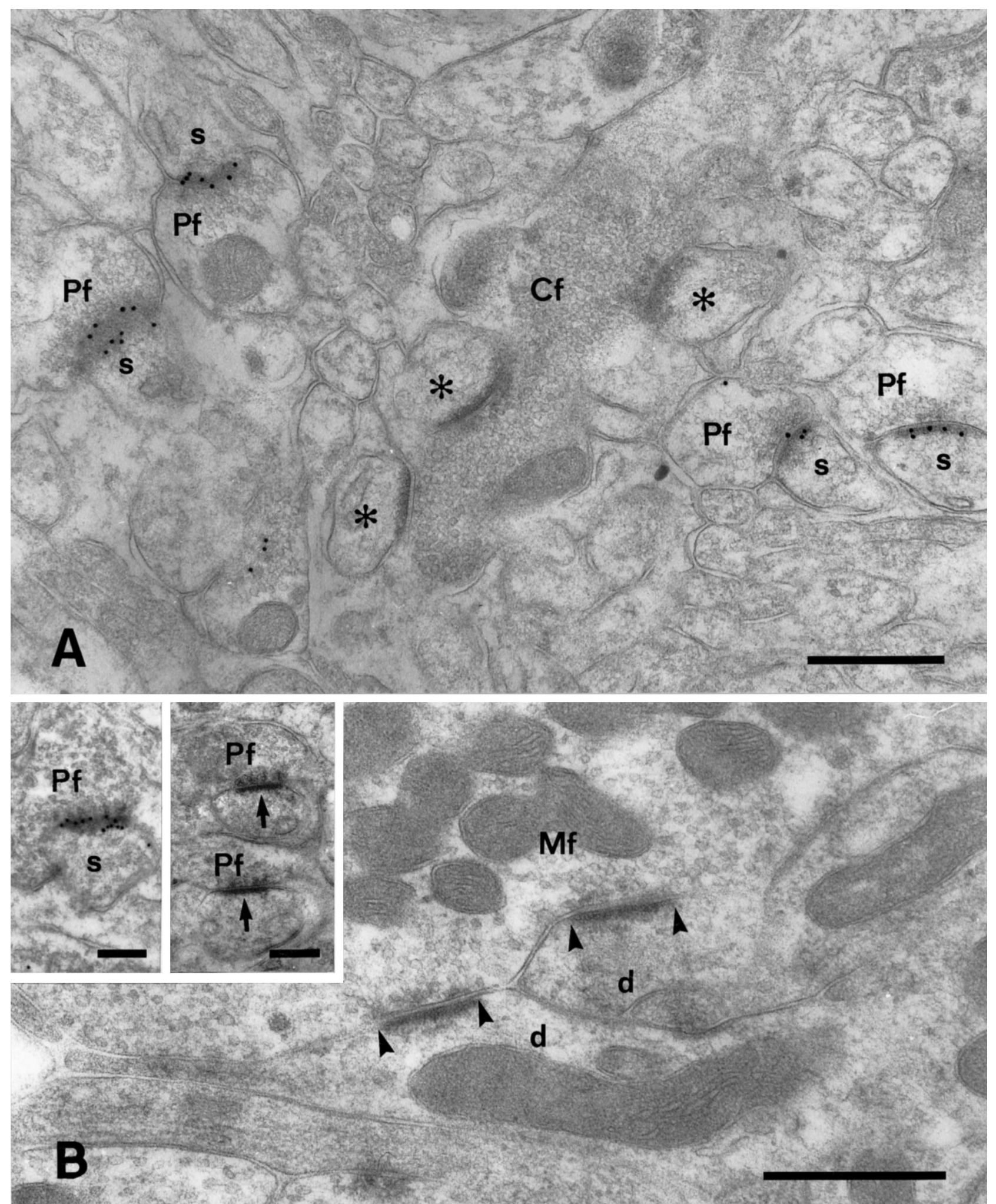

Figure 2. Immunolabeling for the $\delta$ receptor is absent from synapses between climbing fibers $(C f)$ and Purkinje cell spines (asterisks) and between mossy fibers $(M f)$ and granule cell dendritic digits $(d)$. Arrowheads in $B$ delimit postsynaptic densities. $A$ and $B$ are from the same section as Figure 1. $B$, Insets, Immunolabeling for the $\delta$ receptor is abolished after preadsorption with the peptide used for immunization (right; arrows show negative postsynaptic densities) but remains after preadsorption with the peptide used to generate the GluR2/3 antibody (left). Pf, Parallel fibers; $s$, Purkinje cell spines. Gold particles, $15 \mathrm{~nm}$. Scale bars: $A, B, 0.5 \mu \mathrm{m}$; insets, $0.25 \mu \mathrm{m}$. 

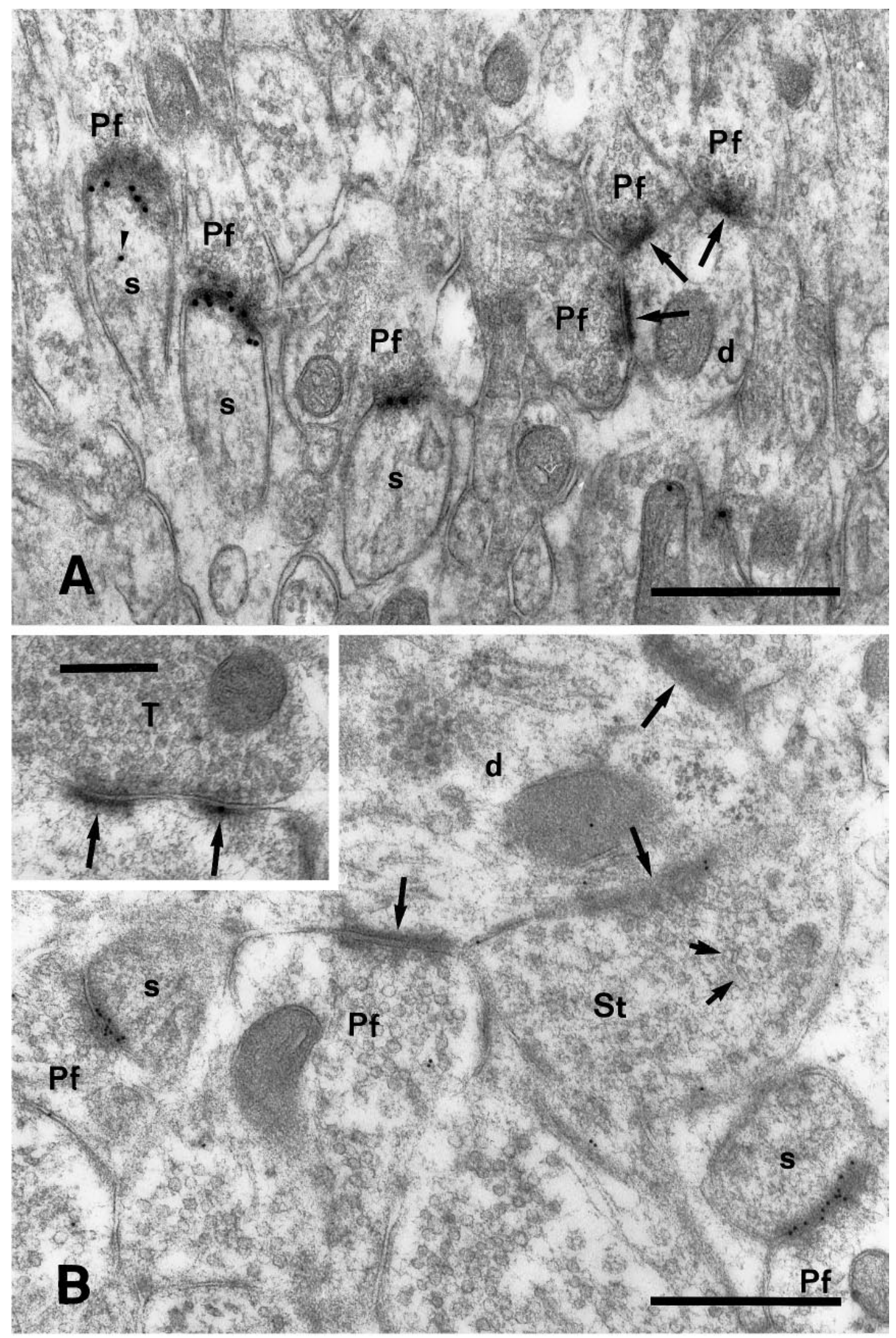

Figure 3. No $\delta$ receptor immunolabeling occurs at synapses between parallel fibers $(P f)$ and dendritic stems $(d)$ or postsynaptic to stellate cell terminals $(S t)$, whereas adjacent parallel fiber synapses with spines $(s)$ show dense labeling. Long arrows indicate negative synapses. Arrowhead in $A$ shows gold particle in spine. The stellate cell synapse in $B$ is obliquely cut but can be identified by the presence of flattened vesicles (short arrows). $B$, Inset, Asymmetric synapse (arrows) established by nerve terminal $(T)$ in stratum oriens in the CA1 of hippocampus. The section was incubated together with the cerebellar section in $A$. The sizes of gold particles were $15 \mathrm{~nm}(A$ and inset in $B)$ or $10 \mathrm{~nm}(B)$, the latter giving a slightly higher background labeling than the former. Scale bars: $A, B, 0.5 \mu \mathrm{m}$; inset, $0.25 \mu \mathrm{m}$. 
Table 2. Synaptic versus nonsynaptic distribution of $\boldsymbol{\delta 2}$ receptor immunoreactivity

\begin{tabular}{|c|c|c|c|c|c|}
\hline & \multirow[b]{2}{*}{ Total } & \multirow{2}{*}{$\begin{array}{l}\text { Parallel fiber } \\
\text { synapses with spines }\end{array}$} & \multirow{2}{*}{$\begin{array}{l}\text { Nonsynaptic } \\
\text { membranes }\end{array}$} & \multicolumn{2}{|c|}{ Cytoplasmic compartments } \\
\hline & & & & Spines & Other \\
\hline Number of particles & $349(100 \%)$ & $311(89 \%)$ & $12(3.4 \%)$ & $7(2 \%)$ & $19(5.4 \%)$ \\
\hline Relative boundary length & $100 \%$ & $3.1 \%$ & $96.6 \%$ & & \\
\hline
\end{tabular}

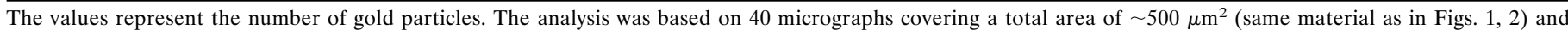

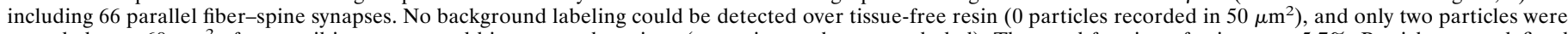

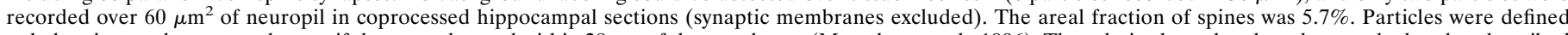

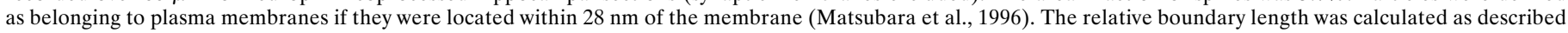
in Materials and Methods.

cause any alterations in the pattern of labeling, whereas omission of the first or second antibody selectively removed the respective gold particle size (data not shown).

Postsynaptic membranes were identified that had been cut more or less tangentially, thus exposing a two-dimensional rather than a linear receptor matrix (Fig. 5G,H). Because of the curvature of the synaptic specialization, only part of it would be accessible to the immunoreagents even if tangentially cut. At such sites it could be seen that the two receptor types did not occupy separate domains, although spots were found in which one or the other gold particle size was in clear excess (Fig. 5H). At the tangentially cut surfaces the density of $5 \mathrm{~nm}$ gold particles representing $\delta$ receptors was typically higher than 10 particles per $10^{4}$ $\mathrm{nm}^{2}$ (e.g., Fig. $5 H$, right). A similar labeling intensity was observed in tangentially cut postsynaptic membranes labeled with $15 \mathrm{~nm}$ gold particles (data not shown). As was the case for the larger gold particle sizes, the $5 \mathrm{~nm}$ gold particles were restricted to parallel fiber synapses with spines.

\section{DISCUSSION}

\section{The $\delta 2$ receptor is expressed selectively at parallel fiber-Purkinje cell synapses}

The $\delta$ receptors belong to the superfamily of glutamate receptors (Yamazaki et al., 1992; Araki et al., 1993; Lomeli et al., 1993). Although the role of the $\delta 1$ subunit remains obscure, it was shown recently that knockout of the $\delta 2$ subunit produces severe deficits in motor coordination and cerebellar long-term depression (Kashiwabuchi et al., 1995). In the same study, electrophysiological evidence was obtained of multiple climbing fiber innervation. To translate these findings into a better understanding of cerebellar function, we needed to identify the precise loci of $\delta 2$ receptor expression. Although previous evidence has pointed to its localization in Purkinje cells and at parallel fiber-spine synapses (Araki et al., 1993; Lomeli et al., 1993; Hirano et al., 1994, 1995; Mayat et al., 1995; Petralia et al., 1995; Takayama et al., 1995), it must be resolved whether the $\delta 2$ receptor also occurs at other synaptic sites, whether it is expressed presynaptically or in nonsynaptic membranes, and how it is associated with AMPA receptors at the synaptic and subsynaptic levels. With immunocytochemistry such issues can be settled by use of particulate markers, which are nondiffusible and thus provide a spatial resolution limited mainly by the molecular sizes of the immunoglobulins or immunoglobulin fragments (Ottersen, 1989; Kellenberger and Hayat, 1991).

Because postembedding immunogold labeling is restricted to those epitopes that are exposed at the surface of the section, a low labeling intensity is a recurrent problem when this approach is applied to glutamate receptors. However, by optimizing the conditions for tissue preparation and immunoincubation (Matsubara et al., 1996), it has been possible to achieve a sensitivity that permits a quantitative analysis of the issues mentioned above.

The present study revealed a remarkable selectivity in the synaptic expression of $\delta$ receptors in the cerebellar cortex. All synapses between parallel fibers and Purkinje cell spines appeared to be labeled, although no significant labeling was associated with other types of synapse. The same pattern was reproduced with three different gold particle sizes. Nevertheless, absence of labeling in a particular type of synapse must be interpreted with caution. Masking of antigens could pose a problem, but the occurrence of AMPA immunogold labeling in synapses devoid of $\delta$ receptor immunoreactivity (climbing fiber synapses with spines and parallel fiber synapses with dendritic stems) shows that the receptor matrix in these synapses is accessible to the immunoreagents. Further, the sensitivity remains an issue to be considered, despite recent improvements. Although the labeling efficiency cannot be defined in absolute terms, it must be quite high, as judged by the close spacing of gold particles at tangentially cut synaptic specializations. Even a very small pool of receptors should be picked up by the procedure in the absence of significant background labeling. Thus it would seem reasonable to conclude that the $\delta$ receptor density must be orders of magnitude higher in the parallel fiber-spine synapses than in other types of synapse in the cerebellar cortex.

The antibody used here recognizes the $\delta 1$ receptor as well as the $\delta 2$ receptor (Mayat et al., 1995). To assess the extent to which the $\delta 1$ receptor had contributed to the present pattern of immunolabeling, we processed the cerebellar sections together with hippocampal sections from the same animals. In situ hybridization analyses have shown that, although the hippocampus does not contain detectable levels of $\delta 2$ subunit mRNA (Araki et al., 1993; Lomeli et al., 1993), it is the brain structure that is richest in $\delta 1$ mRNA (Lomeli et al., 1993). The very weak labeling obtained by the $\delta$ receptor antibody in synapses of coprocessed hippocampal sections suggests that the labeling in the cerebellum is attributable primarily to the presence of the $\delta 2$ receptor. This would agree with previous observations based on other approaches (Mayat et al., 1995). In the remaining Discussion, the labeling will be considered to reflect the $\delta 2$ receptor distribution.

The absence of detectable $\delta 2$ receptor expression postsynaptic to climbing fibers implies that the Purkinje cell can target this receptor subunit to a specific subpopulation of its spines. It is also clear that $\delta 2$ receptor expression is not induced indiscriminatively by parallel fibers, because such receptors were not found at parallel fiber synapses with stem dendrites of interneurons. The results suggest that the expression of the $\delta 2$ receptor is contingent on a unique combination of pre- and postsynaptic elements. 

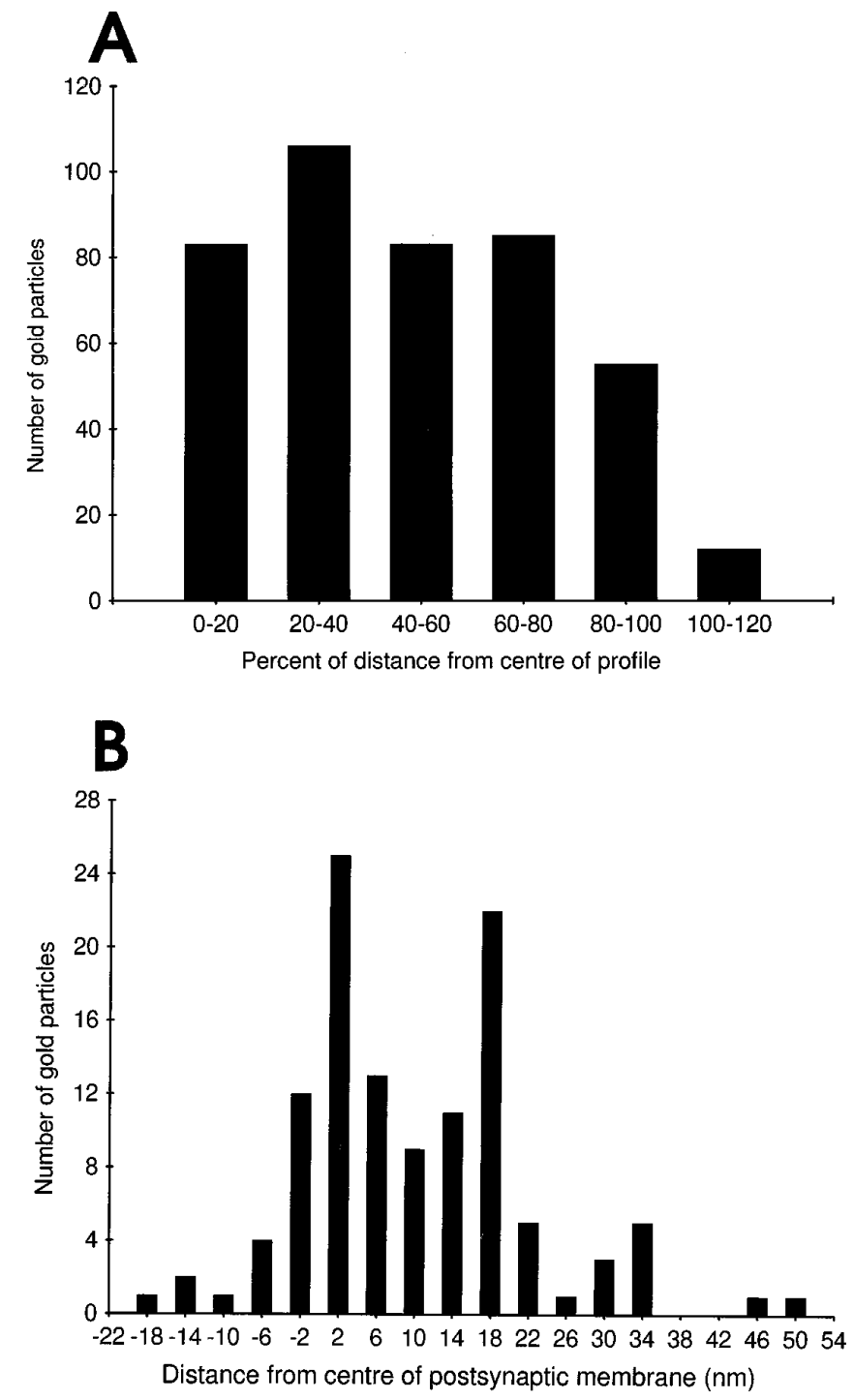

Figure 4. Tangential $(A)$ and perpendicular $(B)$ distribution of $\delta$ receptor immunoreactivity at the parallel fiber-spine synapses. Only synapses with distinct and transversely cut postsynaptic membranes were included in the analysis. Same material as in Figures 1 and 2. A, Immunolabeling occurs along the entire mediolateral extent of the postsynaptic density, but the concentration of particles shows a slight decrease near the margin of the synapse. This decrease can be explained on methodological grounds if one takes into account that the gold particle density at any one point is a function of the antigen concentration within a radius of $\sim 28 \mathrm{~nm}$ (Matsubara et al., 1996) Similarly, the few particles situated lateral to the margin of the postsynaptic thickening can be attributed to epitopes located in the thickening itself Synapses $(n=68)$ were selected for analysis only if the radius of the postsynaptic density profile exceeded $150 \mathrm{~nm}$. This should ensure the inclusion of central as well as peripheral parts of the density (the diameter of the postsynaptic density is in the range of $250-500 \mu \mathrm{m}$; Palay and Chan-Palay, 1974). The abscissa indicates the mediolateral extent of the postsynaptic density in percentage of distance from the center of the profile $(0 \%)$ to the margin $(100 \%)$. $B$, Gold particles signaling the $\delta$ receptor are found predominantly at the postsynaptic side of the postsynaptic membrane $(n=23)$. The distances between the centers of the gold particles and the midpoint of the postsynaptic plasma membrane were grouped into bins $4 \mathrm{~nm}$ wide (bin centers indicated; minus signs denote bins presynaptic to the reference point).

\section{The $\delta 2$ receptor occurs at low concentrations in nonsynaptic compartments}

Only $\sim 3 \%$ of the gold particles signaling the $\delta 2$ receptor were associated with nonsynaptic membranes. This suggests that the functional impairments observed after $\delta 2$ receptor knockout (Kashiwabuchi et al., 1995) must be understood on the basis of a selective effect on parallel fiber-spine synapses and that glial or other nonsynaptic membranes are not primarily involved. Also, the cytoplasmic pool of receptor protein seemed to be small, as compared with the synaptic pool. A detailed analysis of the cytoplasmic pool was outside the scope of the present study.

\section{Organization of $\delta 2$ receptors at the parallel fiber-spine synapse}

Recently, it has become clear that different glutamate receptors have distinct patterns of distribution at the synapse and that this may have important functional implications (Hayashi et al., 1993; Nusser et al., 1994; Baude et al., 1995; Chittajallu et al., 1996; Petralia et al., 1996; Shigemoto et al., 1996). Although several types of metabotropic receptor have been localized to the presynaptic membrane or lateral to or at the periphery of the postsynaptic density, the AMPA receptor subunits seem to occur at high concentrations in the postsynaptic specialization itself (Baude et al., 1995; Phend et al., 1995; Matsubara et al., 1996; Popratiloff et al., 1996). Specifically in the case of the parallel fiber synapses, immunogold techniques revealed that $\operatorname{mGluR} 1 \alpha$ is located peripherally in the synapse, whereas AMPA receptor subunits were found over the main body of the synaptic specialization (Baude et al., 1993; Nusser et al., 1994). The recent finding in a peripheral glutamate synapse that AMPA receptors may be distributed heterogeneously within a single postsynaptic specialization (Matsubara et al., 1996) opens up the possibility that the different ionotropic receptors are not inserted in the synaptic membrane in a random manner but are targeted preferentially to specific parts of the receptor matrix.

The $\delta 2$ receptors do not seem to form functional ion channels when expressed in transfected cells (Araki et al., 1993; Lomeli et al., 1993), yet in terms of their subsynaptic organization they are to be grouped together with the ionotropic glutamate receptors rather than with the metabotropic ones. Thus, the present data suggest that the $\delta 2$ receptors are restricted to the postsynaptic specialization. The few gold particles that were found lateral to the specialization may be accounted for by the length of the immunoglobulin "bridge" between the epitope and gold particle (see legend to Fig. 4).

Because LTD is believed to be expressed via alterations in the properties or number of AMPA receptors (Linden, 1994), it was of interest to examine the spatial relation between the $\delta$ and AMPA receptor molecules. The double-labeling data indicated that both types of receptor are expressed along the entire extent of the postsynaptic density and that they do not form separate domains. This arrangement opens for a relatively direct interaction between the two receptors, which could be relevant in LTD (Hirano et al., 1995). Whether AMPA and $\delta$ receptors physically are coupled or coassembled cannot be resolved at the resolution of immunogold procedures, but immunoprecipitation experiments have not provided evidence in support of this (Mayat et al., 1995).

The distribution of gold particles perpendicular to the synaptic specialization strongly suggests that the epitopes are localized at the cytoplasmic aspect of the postsynaptic membrane, implying an intracellular location of the $\mathrm{C}$ terminus. This is in agreement with the proposed topology of AMPA receptors (Hollmann et al., 1994; Molnar et al., 1994; Bennet and Dingledine, 1995) with which the $\delta 2$ receptor shares a $21-24 \%$ amino acid sequence identity (Araki et al., 1993). The gold particle distribution revealed no peak that could indicate the presence of a presynaptic pool of $\delta 2$ receptors. 

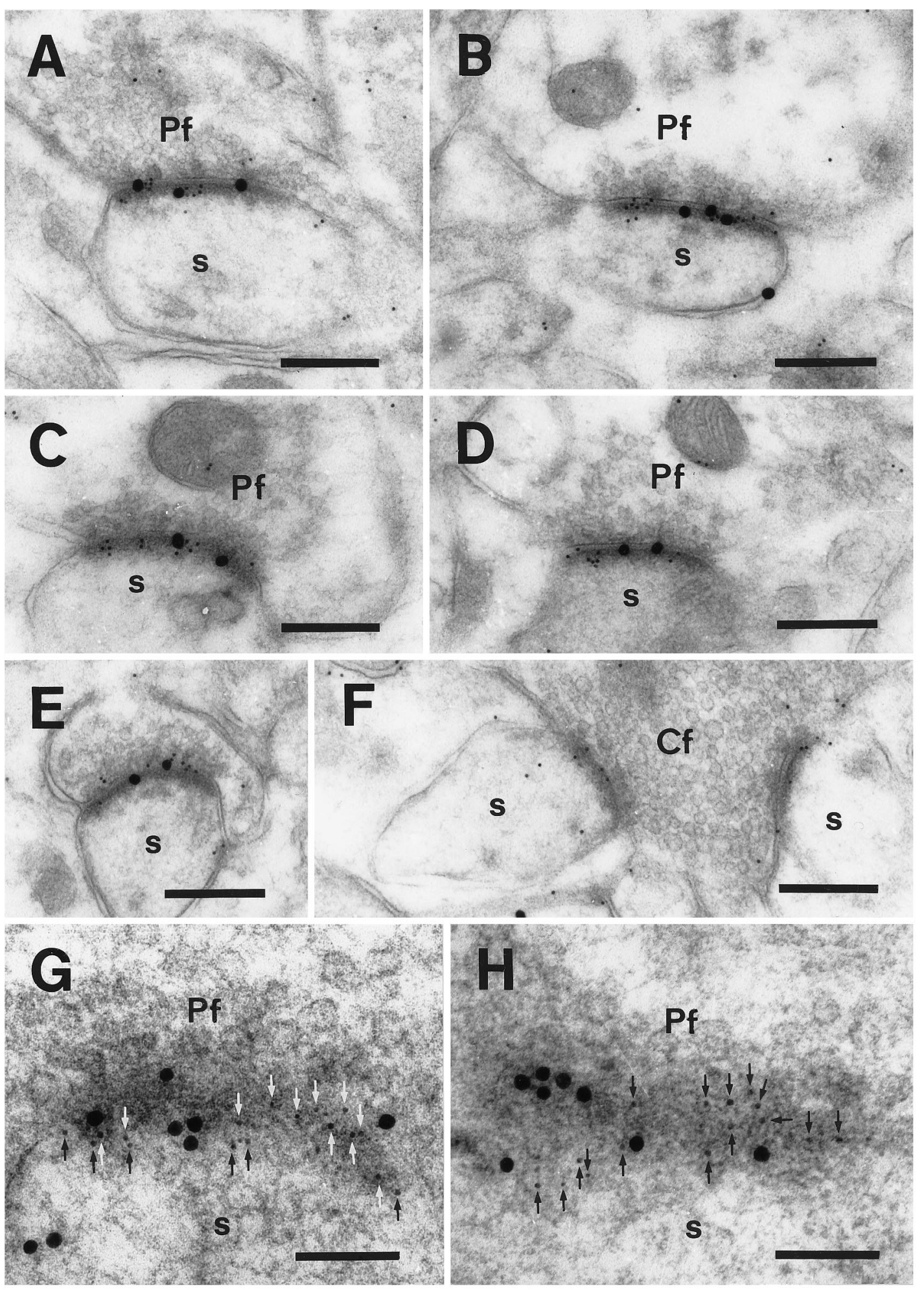

Figure 5. Double labeling with antisera to the $\delta$ receptor ( $30 \mathrm{~nm}$ particles in $A-F, 5 \mathrm{~nm}$ particles in $G, H$ ) and GluR2/3 $(10 \mathrm{~nm}$ in $A-F, 15 \mathrm{~nm}$ in $G, H)$. Double labeling is found at synapses between parallel fibers $(P f)$ and Purkinje cell spines $(s)$, whereas climbing fibers $(C f)$ establish synapses that are single-labeled for GluR2/3 $(F)$. Synapses in $G$ and $H$ are obliquely cut so that parts of the postsynaptic membranes are viewed en face. Some of the $5 \mathrm{~nm}$ particles are indicated by arrows. The distance between these particles is typically in the range of 15-30 nm (H, right part). Scale bars: $A-F, 0.25 \mu \mathrm{m} ; G, H, 0.1 \mu \mathrm{m}$.

\section{Conclusions}

To our knowledge this is the first high-resolution immunogold analysis of a member of the $\delta$ glutamate receptor family. The data suggest that the $\delta 2$ subunit is targeted to the spines that are postsynaptic to parallel fibers, but not to those that are postsynaptic to the climbing fibers, which form the other main excitatory input to the Purkinje cells. In contrast, AMPA receptors are expressed in both types of synapse. This shows that postsynaptic 
neurons may compose distinct glutamate receptor profiles dependent on the identity of the presynaptic element. The organization of the $\delta 2$ receptors in the postsynaptic membrane mimics that of AMPA receptors in regard to tangential distribution (highly concentrated in postsynaptic specialization) and membrane topology (intracellular C terminus). The two types of receptor show a close spatial association that could underlie their ability to interact in conditions of synaptic plasticity.

\section{REFERENCES}

Araki K, Meguro H, Kushiya E, Takayama C, Inoue Y, Mishina M (1993) Selective expression of the glutamate receptor channel delta 2 subunit in cerebellar Purkinje cells. Biochem Biophys Res Commun 197:1267-1276.

Baude A, Nusser Z, Roberts JDB, Mulvihill E, McIlhinney RAJ, Somogyi $\mathrm{P}$ (1993) The metabotropic glutamate receptor (mGluR1 $\alpha$ ) is concentrated at perisynaptic membrane of neuronal subpopulations as detected by immunogold reaction. Neuron 11:771-787.

Baude A, Nusser Z, Molnár E, McIlhinney RAJ, Somogyi P (1995) High-resolution immunogold localization of AMPA-type glutamate receptor subunits at synaptic and nonsynaptic sites in the rat hippocampus. Neuroscience 69:1031-1055.

Bennet JA, Dingledine R (1995) Topology profile for a glutamate receptor: three transmembrane domains and a channel-lining reentrant membrane loop. Neuron 14:373-384.

Chaudhry FA, Lehre KP, van Lookeren Campagne M, Ottersen OP, Danbolt NC, Storm-Mathisen J (1995) Glutamate transporters in glial plasma membranes: highly differentiated localizations revealed by quantitative ultrastructural immunocytochemistry. Neuron 15:711-720.

Chittajallu R, Vignes M, Dev KK, Barnes JM, Collingridge GL, Henley JM (1996) Regulation of glutamate release by presynaptic kainate receptors in the hippocampus. Nature 379:79-81.

Gundersen HJG, Bendtsen TF, Korbo L, Marcussen N, Møller A, Nielsen K, Nyengaard JR, Pakkenberg B, Sørensen FB, Vesterby A, West MJ (1988) Some new, simple, and efficient stereological methods and their use in pathological research and diagnosis. APMIS 96:379-394.

Hayashi Y, Momiyama A, Takahashi T, Ohishi H, Ogawa-Meguro R, Shigemoto R, Mizuno N, Nakanishi S (1993) Role of metabotropic glutamate receptor in synaptic modulation in the accessory olfactory bulb. Nature 366:687-690.

Hirano T, Kasono K, Araki K, Shinozuka K, Mishina M (1994) Involvement of the glutamate receptor delta 2 subunit in the long-term depression of glutamate responsiveness in cultured rat Purkinje cells. Neurosci Lett 182:172-176.

Hirano T, Kasono K, Araki K, Mishina M (1995) Suppression of LTD in cultured Purkinje cells deficient in the glutamate receptor delta 2 subunit. NeuroReport 6:524-526.

Hjelle OP, Chaudhry FA, Ottersen OP (1994) Antisera to glutathione: characterization and immunocytochemical application to the rat cerebellum. Eur J Neurosci 6:794-804.

Hollmann M, Maron C, Heinemann S (1994) N-Glycosylation site tagging suggests a three transmembrane domain topology for the glutamate receptor GluR1. Neuron 13:1331-1343.

Ito M (1989) Long-term depression. Annu Rev Neurosci 12:85-102.

Kashiwabuchi N, Ikeda K, Araki K, Hirano T, Shibuki K, Takayama C, Inoue Y, Kutsuwada T, Yagi T, Kang Y, Aizawa S, Mishina M (1995) Impairment of motor coordination, Purkinje cell synapse formation, and cerebellar long-term depression in GluR $\delta 2$ mutant mice. Cell $81: 245-252$.

Kellenberger E, Hayat MA (1991) Some basic concepts for the choice of methods. In: Colloidal gold: principles, methods, and applications (Hayat MA, ed), pp 1-30. San Diego: Academic.
Linden DJ (1994) Long-term synaptic depression in the mammalian brain. Neuron 12:457-472.

Lomeli H, Sprengel R, Laurie DJ, Köhr G, Herb A, Seeburg PH, Wisden W (1993) The rat delta-1 and delta-2 subunits extend the excitatory amino acid receptor family. FEBS Lett 315:318-322.

Matsubara A, Laake JH, Davanger S, Usami S-i, Ottersen OP (1996) Organization of AMPA receptor subunits at a glutamate synapse: a quantitative immunogold analysis of hair cell synapses in the rat organ of Corti. J Neurosci 16:4457-4467.

Mayat E, Petralia RS, Wang YX, Wenthold RJ (1995) Immunoprecipitation, immunoblotting, and immunocytochemistry studies suggest that glutamate receptor delta subunits form novel postsynaptic receptor complexes. J Neurosci 15:2533-2546.

Molnar E, McIlhinney RA, Baude A, Nusser Z, Somogyi P (1994) Membrane topology of the GluR1 glutamate receptor subunit: epitope mapping by site-directed anti-peptide antibodies. J Neurochem 63:683-693.

Nusser Z, Mulvihill E, Streit P, Somogyi P (1994) Subsynaptic segregation of metabotropic and ionotropic glutamate receptors as revealed by immunogold localization. Neuroscience 61:421-427.

Ottersen OP (1989) Quantitative electron microscopic immunocytochemistry of amino acids. Anat Embryol (Berl) 180:1-15.

Ottersen OP, Zhang N, Walberg F (1992) Metabolic compartmentation of glutamate and glutamine: morphological evidence obtained by quantitative immunocytochemistry in rat cerebellum. Neuroscience 46:519-534.

Palay SL, Chan-Palay V (1974) Cerebellar cortex: cytology and organization. Heidelberg: Springer.

Petralia RS, Zhao HM, Wang YX, Wenthold RJ (1995) Immunocytochemical localization of glutamate receptor subunits in Purkinje cells in developing and adult rats. Soc Neurosci Abstr 21:838.

Petralia RS, Wang YX, Niedzielski AS, Wenthold RJ (1996) The metabotropic glutamate receptors, mGluR2 and mGluR3, show unique postsynaptic, presynaptic, and glial localizations. Neuroscience 71:949-976.

Phend KD, Rustioni A, Weinberg RJ (1995) An osmium-free method of epon embedment that preserves both ultrastructure and antigenicity for post-embedding immunocytochemistry. J Histochem Cytochem 43:283-292.

Popratiloff A, Weinberg RJ, Rustioni A (1996) AMPA receptor subunits underlying terminals of fine-caliber primary afferent fibers. J Neurosci 16:3363-3372.

Shigemoto R, Kulik A, Roberts JDB, Ohishi H, Nusser Z, Kaneko T, Somogyi P (1996) Target-cell-specific concentration of metabotropic glutamate receptor in the presynaptic active zone. Nature 381:523-525.

Takayama C, Nakagawa S, Watanabe M, Mishina M, Inoue Y (1995) Light and electron microscopic localization of the glutamate receptor channel delta 2 subunit in the mouse Purkinje cell. Neurosci Lett 188:89-92.

van Lookeren Campagne M, Oestreicher AB, van der Krift TP, Gispen WH, Verkleij AJ (1991) Freeze-substitution and Lowicryl HM20 embedding of fixed rat brain: suitability for immunogold ultrastructural localization of neural antigens. J Histochem Cytochem 39:1267-1279.

Wang B-L, Larsson L-I (1985) Simultaneous demonstration of multiple antigens by indirect immunofluorescence or immunogold staining: novel light and electron microscopical double and triple staining method employing primary antibodies from the same species. Histochemistry $83: 47-56$.

Wenthold RJ, Yokotani N, Doi K, Wada K (1992) Immunocytochemical characterization of the non-NMDA glutamate receptor using subunit specific antibodies. J Biol Chem 267:501-507.

Yamazaki M, Araki K, Shibata A, Mishina M (1992) Molecular cloning of a cDNA encoding a novel member of the mouse glutamate receptor channel family. Biochem Biophys Res Commun 183:886-892. 